\title{
Assam Origins in Relation to Oceania*
}

\author{
By Prof.. J. H. Hutton, C.I.E.
}

$\mathrm{I}^{\mathrm{N}}$ choosing this subject I am not attempting to offer any definite solution to the problems of Indonesian migrations, but propose rather to examine one aspect of them in the hopes that I may elicit further information which may contribute towards the ultimate solution of what is really a complex of very difficult problems, as I feel that although a clearing up of the main question may be very distant, some analysis of the Assam side of the problem is perhaps possible.

Many parallels are to be found of one sort or another between Assam and Oceania, some of which were pointed out by Sir Henry Yule and by S. E. Peal in articles in the Journal of the Anthropological Institute in February 1880 and 1893 respectively, and others of which I myself indicated in an article on "Assam and the Pacific", in Man in India in 1924. In 1925 Henry Balfour pointed out cultural connexions between Assam and Indonesia in the matter of certain types of thorn-lined fish traps and, more recently, of fretted horn and shell ear ornaments.

It is fairly clear that identity of culture, in so far as it exists, is not that of a single culture, but rather of a complex of cultures in each case. It is certain that Assam may be able to throw some light on the Indonesian problem, as the stratifications can, at any rate to some extent, still be traced. The last immigrants are undoubtedly people of Kuki and Kachin affinities. There is a strong tradition among the Chins of the Arakan hill tracts pointing to their migration down the Chindwin Valley, no doubt throwing off parties which must have penetrated the Assam hills from the east on the way, after which one portion of the Kukis at any rate seem to have worked up northwards again from the Bay of Bengal, a movement which has barely ceased, if it has ceased, in the present generation. It would seem that the Kayans of Borneo probably formed part of the same movement. A tradition quoted by Hose and McDougall assigned the arrival of the Kayans in Borneo to the earliest years of the fourteenth century A.D., a date which fits well enough with Kuki and Tippera tradition.

Apart from such preceding migrations, of which there may have been many originating in movements in the Chindwin Valley caused by this southward Kuki-Kachin migration, and of which we probably have a memory in the traditions of

- From the presidential address to Section H (Anthropology) of the British Association, delivered at Nottingham on September 3. the Angami Lhota and Ao movements from Manipur westwards, the two previous cultures in the Assam hills seem to have been definitely matrilineal and to have belonged to two types. One of these-and presumably the later-seems to have been analogous to the present Khasi and Synteng cultures, the other to that of the Garo and of the Kachari of the Assam plains. The Khasi migration clearly came from the east, and the parallel culture in Tonkin to their earliest remains in Assam is dated by Coèdes to about the beginning of our era. The Garo-Kachari peoples seem to have migrated from the north bank of the Brahmaputra, and while the Kachari is now predominantly patrilineal, as the Garo is matrilineal, both may still be said to be in the process of change as the result of contact between two systems.

It is interesting to notice that in Madagascar the Vazimba, who preceded the Hova as immigrants, had a number of features in common with the megalith-using Khasi, not all of which were afterwards adopted by the Hova. The latter, for example, built in wood, whereas the Vazimba used stone. One may also observe that Hocart, writing on the early Fijians, is inclined to think that the more civilized community was swamped by barbarians before the more recent migration of Polynesians from the east. Undoubtedly the Naga tribes at present represented by the Konyak Nagas in the north and to a lesser degree by Kachha Nagas to the south of the Naga hills, are associated with a more civilized culture in some respects than that of the intervening tribes who have come up from Manipur, always excepting the Angamis, who are in many respects sui generis and who probably have incorporated a very great deal of the civilization which preceded them on their present sites.

One important feature of the Konyak tribes, shared, it is true, by their neighbours the Aos, and in a ruder fashion by the Sangtam, Chang and Yimtsungr of the east, is the possession of enormous slit wood gongs to which I give the name 'canoe gong' on account of their shape. S. E. Peal was the first to report on these gongs, which he called 'canoe drums'; Prof. Henry Balfour calls them xylophones, and the only reason that I do not adopt his term is that I prefer to keep that name for the more usual type of xylophone consisting of a number of slats of wood giving different notes when beaten which is found among the Kuki, though not among the Naga tribes. These canoe gongs are the basis of an important cult intimately 
associated with head-hunting, and strongly suggestive of much that is associated with canoes in Oceania.

The true canoe gong with carved figure-heads and long hull like that of a dug-out is almost entirely limited to the Konyak, Ao, Chang and Sangtam tribes, and of these four undoubtedly the Chang and the Ao contain a large admixture of Konyak blood. The Sangtam only use a typical canoe gong in those villages which march with the Ao and Chang country. Farther south the shape is much less elaborate, and the Yimtsungr to the east of them used a mere hollow tree-trunk. South of the Sangtam tribe the canoe gong completely disappears except for the following instance : the Tangkul tribe use a remarkable form of gong, hitherto, I believe, unpublished, which might be described as resembling an inverted boat, the two ends of which are skeleton, while the centre part consists of the usual slit gong of more or less cylindrical type. The Angami use an unornamented wooden vessel of similar shape (without the skeleton ends) for the reception of liquor in bulk on ceremonial occasions, and one recalls Ellis's account of the man of Rurutu who came off to meet him "at a distance of two miles" from the island in a wooden food-vessel 6 feet long and 18 inches to 2 feet wide. A smaller slit gong of somewhat similar pattern, but much simpler, is used for scaring the birds from their fields by the Kachha Naga. Farther south again, the Zanniat Chins, who, unlike the other Chins, have a democratic organization, have a small slit gong not more than 6 feet long very like the Angami vat, while the Ngawn Chins use one of the same size not unlike the South American teponatzli, and put food in it on the occasion of a ceremonial dance.

It is interesting to observe that in South America the canoe gong appears to have developed independently from a hollow tree. It is, of course, possible that the canoe gong of the Naga hills has similarly developed from a tree trunk, but since we find no example of signalling by hammering on trees, we are perhaps entitled to argue that the process in Assam has been the other way, and that the smaller slit gongs, or the hollow tree trunks, used by some villages, are degenerate forms of the original gong which started as a canoe, and it is possibly significant that in the Kachin story of the great flood the two survivors escape drowning in "a large oval-shaped drum". On the other hand, it must be admitted that a simple form of slit gong occurs in Yunnan, as it does in Malaya and in Borneo, suggesting either marginal degenerations from a developed type in Assam, or possibly simple types from which the Assam one might have been elaborated. The real argument, therefore, for the canoe gong's being a survival from a real canoe rests on its associations with head-hunting and a typical canoe culture.

Now the Naga canoe gong is closely associated with the men's house, and generally, if not kept in it, it is kept in an annexe. It is in some respects treated almost as an idol, and tremendous effort is expended on carving it and dragging it up to the village. All human heads brought in are first placed on the canoe gong, at any rate by the Ao, suggesting the Marquesan practice of decorating the prows of their war canoes with the skulls of their enemies. When the gong is dragged up to the village over wooden rollers, such as those used in launching a vessel, the blood of the sacrificed animals is poured on to it, and in the old days any stranger, whether friend or foe, who came to the village on the day when a new drum was dragged in, was killed in order that his head might adorn the drum and his soul inhabit it. Indeed, until a head had come in, or had been brought in for the drum, a fence was put round it which could not be removed, nor could the drum be beaten until the young men had been out and fetched a head to remedy the defect. This head was first laid on the new drum.

The parallel with Melanesian canoe practice is here very close. Codrington writes as follows : "In the eastern Solomon Islands, if no victim was met with in the first voyage of a new canoe, the chief to whom the canoe belonged would privately arrange with some neighbouring chief to let him have one of his men, some friendless man probably, or a stranger, who would then be killed, perhaps as he went out to look at the new canoe. . . . Further west also captives were kept with a view to the taking of their heads when new canoes were launched." He goes on to give an example in a footnote: "The chief of Ravu bought his peko [war canoe] . . . for a large sum of money. It was brought over secretly and put into a... . canoe house, where it stood till a head should have been procured. . . . In the morning a single man came by . . . in his canoe . . . they caught and killed him, set up his head at the prow of the [newly bought] canoe and paddled back to Ravu with shouting and blowing conch shells.'

Nowadays in the Ao country a mock raid takes the place of a real one, but even this chastened sacrifice leads to a great success in hunting and in agriculture. The Ao gong nowadays wears a necklace of basket balls representing heads. Real heads were never used in this way, although they were laid on the gong when first brought in. These basket-work ornaments perhaps afford a parallel with the carved head which formed part of the figure-head of the Melanesian canoe. The figurehead of an Ao canoe is generally in the form of a buffalo or gayal head, that of the Konyak tribes 
an elephant, buffalo or hornbill head, but Peal, writing in 1893, remarks that the Konyak figurehead is (as depicted in his drawing) a crocodile, although "there are no crocodiles in these hills", and he points out that it is a familiar decoration in Indonesia and the Pacific. Although I have covered most of the ground visited by Peal in the last century, I have never seen any figure-head resembling the head of a crocodile, so that this tradition has apparently disappeared in the forty years since he visited the Naga hills.

It has occurred to me that the instruments used for beating the Naga canoe gong may conceivably be degenerate paddles. The ordinary type is more like the dumb-bell than anything, but often one end of the dumb-bell takes an ornamented form such as the hornbill's head, and in any event this 'dumb-bell' is not unlike a paddle in which the blade has degenerated to proportions similar to those of the handle.

F. E. Williams, writing of the Pairama ceremony in the Purari Delta in Papua, tells us that "when a successful hunt returned at evening the corpse of the victim was borne from the canoe to the ravi amid great enthusiasm. The men uttered that prolonged shout or roar which has a singularly exciting effect upon the listener, and rattle their paddles upon the sides of the canoes with the rhythm called raruki raruki. . . . On the following day the ... hunter who first brings down the victim ... is paraded in triumph through the village standing astride the canoe and balancing himself with a spear". It was formerly the custom of Meithei to signal across the Logtak Lake in the Manipur State in Assam by beating with their poles or paddles on the sides of their dug-outs as the Nagas do on a canoe gong, and I am further told by Mr. William Shaw, who served many years in the Manipur State, that some Kabui villages which have no canoe gongs still have the tradition of having used them once, while in Kabui Khulen village a sort of boat, with a high prow, is dragged in every year at the harvest festival "for all who have died in the past year". The best dressed of the young men rides on the boat, while there is a tug-of-war between the two clans of the village, one pulling at each end of the boat by ropes attached to pierced lugs left on when fashioning this dug-out, which is known as the thingkhutong-the plank to which a dead body is ordinarily fastened for burial in that village being called thingkhu. It must, I think, represent a boat or a boat-shaped coffin and be associated again with the fertility of the crops, so largely bound up both with the spirits of the ancestral dead, and of dead enemies, while the riding of the boat by the young warrior is reminiscent of the Pairama ceremony described by F. E. Williams.
Boat-shaped coffins are found occasionally in several of the Naga tribes, particularly in the Konyak country, where in one village at any rate they are associated with a tabooed chief, and it is worth noticing that a stone is put up by the Fijian 'spirit house' for each corpse brought in, precisely as the Konyak Nagas put up an erect stone outside the men's house for each head ; and it is also remarkable that in one case, at any rate, there seems to have been a close association between the Fijian war canoe and the gong known as lali, since the chief Rokona named his war canoe Vatutulali, after his large gong.

The Samoans have a similar gong known as longo, the sound of which-according to Brownwill carry for twenty miles under favourable conditions. Brown also mentions that the Samoans struck the sides of their canoes with the handles of their paddles to mark time.

One more parallel is worth indicating in connexion with this subject. Writing in the Journal of the Royal Society of Arts of February 1937, La Valette illustrates the uptilted roofs of a branch of the Toradja tribe in Celebes, which he says are deliberately got from the prow and stern of a canoe, and are "bound up with the tribal traditions of their ancestors, who originally arrived from a country overseas to which the spirits of the dead must return". The roofs he illustrated are almost identical with forms common in one branch of the Konyak Nagas, east of the frontier of Assam.

I have elsewhere suggested a possible migration from Indonesia, and migrations from Indonesia to Ceylon and South India are placed by Hornell at about the beginning of the Christian era. I cannot help thinking that if, as I am tempted to believe, there was an Indonesian migration which swept upwards northwards into Assam before the Kukis came south, it must have been at an earlier date than that; at any rate there does seem to have been some expansion in many directions from Indonesia at a date which perhaps precedes the dates suggested by Coèdes and Colani for the megalithic civilization of south-east Asia. It would be interesting to know how far the stratifications of cultures in Oceania will correspond to the apparent succession in Assam of an Oceanic canoe culture, a matrilineal megalithic culture and that of a more recent patrilineal one associated with the Kayan and Kuki. The principal point which I wish to make, however, is that the hill cultures of Assam correspond to other distant cultures or combinations of cultures, all of which appear to be marginal in distribution from an Indonesian centre, and that there is some ground for supposing that migrations of culture, if not of people, have taken place from some centre in or near the Indian archipelago in various directions, one of which terminated in Assam. 